\title{
Invasive seaweed enhances recruitment of a native bivalve: roles of refuge from predation and the habitat choice of recruits
}

\author{
Paul E. Gribben ${ }^{1, *}$, Jeffrey T. Wright ${ }^{2}$ \\ ${ }^{1}$ Centre for Marine Biofouling and Bio-Innovation, University of New South Wales, New South Wales 2052, Australia \\ ${ }^{2}$ Institute for Conservation Biology and School of Biological Sciences, University of Wollongong, \\ New South Wales 2522, Australia
}

\begin{abstract}
Invasive species may have a range of negative effects on native species in the region invaded. The invasive green alga Caulerpa taxifolia has invaded several temperate regions worldwide and now occurs in 9 estuaries in temperate eastern Australia. Despite the threat posed by $C$. taxifolia, virtually nothing is known of its effects on native estuarine infauna. In the present study, we investigated the distribution and abundance, habitat choice and predation of recruits (post-set juveniles) of the native Sydney cockle Anadara trapezia at 2 sites invaded by C. taxifolia in Lake Conjola, New South Wales, Australia. Recruitment of A. trapezia was significantly higher in C. taxifolia (both with sparse [30\%] and with dense [100\%] cover) than in Zostera capricorni and bare sediment. Up to 680 recruits $\mathrm{m}^{-2}$ were observed in C. taxifolia, with the highest recruit densities occurring at intermediate $C$. taxifolia densities. However, in habitat choice experiments, recruits showed no preference for $C$. taxifolia over the seagrasses Z. capricorni and Halophila ovalis, but a strong preference for adult $A$. trapezia over all macrophytes when $A$. trapezia were included as treatments in experiments. Field data showed that adult $A$. trapezia in bare sediments had very few recruits attached to them $\left(<0.07\right.$ recruits adult $\left.^{-1}\right)$ compared to adults found within $C$. taxifolia $(0.95 \pm 0.25$ and $1.23 \pm 0.31$ recruits adult ${ }^{-1}$ at the 2 sites). Given that recruits displayed a strong preference for adults, but were rare on adults living in bare sediments, we tested whether $C$. taxifolia provided a refuge from predation. Recruits on adults placed into a bare sediment habitat were all consumed by predatory fish within $15 \mathrm{~min}$, whereas none of the recruits on adults in an adjacent $C$. taxifolia habitat were eaten. Our results show that recruits do not reject $C$. taxifolia as a recruitment substratum despite showing preference for adult conspecifics, and that $C$. taxifolia may, by providing recruits with a refuge from predation enhance the recruitment of $A$. trapezia compared to uninvaded sediment. Although the long-term consequences of this enhanced recruitment are unknown, our study demonstrates that, contrary to commonly held views, the effects of $C$. taxifolia are not always negative.
\end{abstract}

KEY WORDS: Anadara trapezia - Bivalve · Caulerpa taxifolia $\cdot$ Habitat choice Invasion biology Juveniles $\cdot$ Predation $\cdot$ Recruitment $\cdot$ Settlement cues $\cdot$ Soft sediment

\section{INTRODUCTION}

Invasive species represent a serious threat to natural ecosystems (Mack et al. 2000). In a soft-sediment marine context, invasive species have negative impacts through competition (Talman \& Keough 2001), predation (Grosholz et al. 2000, Ross et al. 2003) and the alteration of habitat characteristics (Levi \& Francour 2004). However, the response of natural communities to invasive species is complex, and impacts can have positive, negative, or no effects, depending on the species, location, age, or type of habitat considered (Neira et al. 2005). Recently, the role of invasive species in adding habitat complexity to previously 
unvegetated soft sediments has received attention (see Crooks 2002 for review). Areas of soft sediment with invasive gastropods (e.g. Wonham et al. 2005), matforming mussels (e.g. Crooks 1998) and macrophytes (e.g. Posey 1988, Neira et al. 2005) have higher species diversity and abundance than nearby uninvaded sediment.

The tropical habitat-forming green alga Caulerpa taxifolia has successfully invaded 4 temperate regions around the world (Jousson et al. 2000, Meinesz et al. 2001, Creese et al. 2004). In the Mediterranean and south-eastern Australia it has spread rapidly and often forms large high-density patches (Meinesz et al. 2001, Creese et al. 2004). To date, studies investigating the effects of $C$. taxifolia have almost entirely examined interactions between this species and native seagrasses in the Mediterranean (Ceccherelli \& Cinelli 1997, Jaubert et al. 1999, Ceccherelli \& Sechi 2002). However, Bellan-Santini et al. (1996) demonstrated that the abundance of polychaetes, molluscs and amphipods on hard substrata was lower in C. taxifolia than in reference habitats.

Populations of soft-sediment bivalves found in stable environments, such as sheltered bays and estuaries, are often dominated by high numbers of larger, older individuals (e.g. Richardson \& Walker 1991, Gribben et al. 2004). Recruitment in such populations is often poor, and smaller size or age classes are generally underrepresented even though soft-sediment bivalves are not generally considered recruitment limited (Olafsson et al. 1994). Although pre-settlement processes such as adult-larval interactions and larval supply are important, post-settlement processes such as predation, active habitat selection and post-larval dispersal of recruits (defined in the present study as post-settlement juveniles) are also important in structuring juvenile and adult populations (Olfasson et al. 1994, Nielson \& Franz 1995, Hewitt et al. 1997, Beukema \& Dekker 2003, Cummings \& Thrush 2004).

Soft-sediment environments are rarely homogenous, and even simple structures within the sediment, such as shell material, stones and adult invertebrates can increase spatial heterogeneity and offer small individuals (e.g. recruits) a potential refuge from predation (e.g. Skilleter 1994). The role that complex habitats (often outside the bounds of adult populations), such as seagrasses, play in the persistence of soft-sediment bivalve populations has been widely studied. Several studies have demonstrated decreased rates of predation and increased survivorship of softsediment bivalves in seagrasses compared to nearby unvegetated substrata (e.g. Irlandi \& Peterson 1991, Pecon-Slattery et al. 1991, Irlandi 1994, Skilleter 1994). Enhanced recruitment in seagrass beds compared to that in nearby unvegetated substrata has been explained by seagrass-induced changes in hydrodynamic regimes (see Williams \& Heck 2001 for review).

The invasion of Caulerpa taxifolia into soft sediments in temperate estuaries potentially represents a major perturbation to recruitment of other marine biota into these systems. Because it invades seagrass beds (Villèlle \& Verlaque 1995) and appears to modify sediment properties (Chisholm \& Moulin 2003), C. taxifolia may be detrimental to soft-sediment species. Although the perception is that $C$. taxifolia is detrimental, there are few empirical data to support this assertion (Jaubert et al. 1999, Ceccherelli \& Sechi 2002) and nothing is known about the effects of $C$. taxifolia on the native soft-sediment biota or its potential to influence their recruitment. Indeed, C. taxifolia may even be beneficial if it provides a further source of spatial structure and possible refuge from predation for recruits.

Since its discovery in south-eastern Australia in April 2000, Caulerpa taxifolia has invaded 9 estuaries, and now covers an area of $8.1 \mathrm{~km}^{2}$ (Glasby et al. 2005). $C$. taxifolia colonises soft-sediment habitats by anchoring to the substratum with its rhizoids, which it uses to absorb nutrients (Chisholm et al. 1996). C. taxifolia commonly occurs at depths of 0.5 to $10 \mathrm{~m}$ (Glasby et al. 2005), where it can reach very high abundance (Wright 2005). In March 2005, high numbers of recruits (defined as post-settlement juveniles, 2 to $5 \mathrm{~mm}$ in shell length) of the soft-sediment bivalve Anadara trapezia were observed in Lake Conjola, south-eastern Australia, which has been invaded by $C$. taxifolia (author's unpubl. data). We investigated whether the observed distribution of recruits (post-settlement juveniles) in several bays in Lake Conjola was due to active habitat selection by recruits and whether $C$. taxifolia facilitates the recruitment of $A$. trapezia by acting as a refuge from predation.

\section{MATERIALS AND METHODS}

Study sites and species. Sampling and experiments were undertaken at Sponge Bay and Yooralla Bay in Lake Conjola (351' 44.3" S, 150²6'47.8' E), New South Wales, Australia, a temperate barrier estuary 590 hectares in size. Several native seaweeds and seagrasses inhabit Lake Conjola, but the most abundant macrophyte is Caulerpa taxifolia (Creese et al. 2004). C. taxifolia was first described from Lake Conjola in 2000, but it may have been present there for several years previous to that (Creese et al. 2004). C. taxifolia is spreading in Lake Conjola, and it now covers $>150$ ha of the lake floor and, in many areas, forms large and dense monospecific stands (Creese et al. 2004, Wright 2005). 
The ark shell Anadara trapezia, commonly referred to as the Sydney cockle, is a dioecious, free-spawning bivalve found from Victoria to southern Queensland (Edgar 2000). A. trapezia is generally estuarine, occurring from the intertidal to shallow subtidal $(0$ to $2 \mathrm{~m}$ water depth) in sheltered mud, sand and seagrass habitats. It can reach $75 \mathrm{~mm}$ shell length (Edgar 2000). Both Sponge Bay and Yooralla Bay contain large populations of adult A. trapezia. However, extensive areas of the benthos occupied by $A$. trapezia at both sites are now covered by $C$. taxifolia intermingled with patches of bare sediment. The seagrasses Zostera capricorni and Halophila ovalis are also found fringing the bays, although both are sparse.

Effects of habitat and site on the density of recruits. The density of Anadara trapezia post-settlement juveniles (hereafter referred to as recruits) was sampled in 4 different habitats: bare sediment, Zostera capricorni, dense Caulerpa taxifolia (100\% cover) and sparse C. taxifolia (ca. 30\% cover) in Sponge Bay and Yooralla Bay. The mean $( \pm \mathrm{SE})$ biomass of $C$. taxifolia ( $g$ dry $\mathrm{wt}^{-2}$ ) for dense and sparse C. taxifolia cover determined from 10 randomly selected $0.5 \times 0.5 \mathrm{~m}$ quadrats for each site was $395.1( \pm 35.5)$ and $193.5( \pm 12.1)$, and $388.4( \pm 49.0)$ and $184.5( \pm 15.4)$ in Sponge Bay and Yooralla Bay, respectively. Adult $A$. trapezia were present in all 4 habitats at both sites. Within each habitat at each site, 10 replicate cores $(22.5 \mathrm{~cm}$ diameter $)$ were haphazardly positioned and pushed $10 \mathrm{~cm}$ into the sediment. Adult A. trapezia present in cores were removed, and the number of recruits attached to each adult was recorded. For the $C$. taxifolia and $Z$. capricorni habitats, the macrophytes were then removed from the core and placed into plastic bags. Finally, for all habitats, the top 3 to $5 \mathrm{~cm}$ of sediment were removed from the cores and placed into another plastic bag. The sediment samples were washed through a $1 \mathrm{~mm}$ sieve, and the number of recruits was recorded. In the laboratory, the macrophyte samples were thoroughly searched for recruits, and the number present in each sample was recorded.

We surveyed a further 2 sites (Iron Bark Bay and Pigeon House View) that contained Caulerpa taxifolia, but no adult populations of Anadara trapezia, to determine whether recruits were found at sites where adults were absent. The absence of adult $A$. trapezia at each site was confirmed by haphazardly sampling twenty $0.5 \times 0.5 \mathrm{~m}$ quadrats at water depths where $A$. trapezia are known to occur (i.e. 0 to $2 \mathrm{~m}$ ). The quadrats were thoroughly searched for adults. No adults occurred at either site. To determine the density of recruits, 10 replicate cores were haphazardly positioned in the C. taxifolia habitat at each site. The $C$. taxifolia tissue and the top 3 to $5 \mathrm{~cm}$ of sediment were removed from each core, placed into plastic bags and later searched for $A$. trapezia recruits. We did not distinguish between dense and sparse C. taxifolia habitat at these 2 sites or between bare sediment and $C$. taxifolia.

Although very few adults were recovered from quadrats in the initial survey of the bare and Caulerpa habitats in Sponge Bay and Yooralla Bay, results suggested that there were differences in the number of recruits attached to adults in $C$. taxifolia and bare sediment. In order to more thoroughly examine these differences, we sampled additional adults in each habitat in Sponge Bay and Yooralla Bay for recruits. Adults were selected haphazardly in both habitats, and the number of recruits was recorded for each adult in situ. The total number of adults sampled was 163 (bare, $\mathrm{n}=107$; sparse $C$. taxifolia, $\mathrm{n}=56$ ) in Sponge Bay and 97 (bare, $\mathrm{n}=50$; C. taxifolia, $\mathrm{n}=47$ ) in Yooralla Bay. Zostera capricorni and dense C. taxifolia habitats were not included in this study because Anadara trapezia were rare in these habitats (authors' pers. obs.).

Differences in total recruit density between sites and among habitats (i.e. summed across adults, macrophytes and sediment) were examined using a 2-factor analysis of variance (ANOVA) with the factors site (random) and habitat (fixed), followed by Tukey's pairwise comparisons of means. Data were $\sqrt{ }_{X}$ transformed to meet the requirements of homogeneity of variance.

Habitat choice of recruits. General methods: We investigated whether recruits' choice of different habitats (sediment, macrophytes, or adults) explained the patterns of variation in density in a series of habitatchoice experiments. The experiments consisted of combinations of adult Anadara trapezia (45 to $50 \mathrm{~mm}$ shell length), Caulerpa taxifolia, seagrasses (Zostera capricorni and Halophila ovalis) and sediment (from bare and $C$. taxifolia habitats). All adults, recruits, macrophytes and sediments were collected from Sponge Bay and transported back to the University of New South Wales, where the experiments were conducted. Recruits (2 to $5 \mathrm{~mm}$ shell length) were all collected from C. taxifolia. Prior to use in experiments, the sediment was passed through a $0.5 \mathrm{~mm}$ sieve to remove any organisms and detritus, and the adults, $C$. taxifolia and seagrasses were carefully cleaned of epibionts. Unless otherwise stated, all experiments were conducted in $2.5 \mathrm{l}$ containers (160 mm diameter) filled with $1.5 \mathrm{l}$ of $20 \mu \mathrm{m}$ filtered seawater. All experiments were conducted within $48 \mathrm{~h}$ of collection from Lake Conjola during April 2005. Once the appropriate habitat combinations had been added to the experimental containers, a single recruit was added to the centre of each container. The experiments were left undisturbed for $24 \mathrm{~h}$, after which time the position of 
each recruit was recorded. If a recruit had not selected a habitat (i.e. was found attached to the walls or the bottom of a container), it was recorded as 'no choice'. All habitat-choice experiments were analysed using Pearson's chi-squared tests $(\alpha=0.05)$.

Expt 1-Do recruits show preference for conspecific adults over macrophytes? Expt 1 mimicked the main epibenthic habitat choices available to recruits in the field. Recruits were offered a choice of macrophytes and adult Anadara trapezia. Approximately $2 \mathrm{~g}$ (wet weight) each of Caulerpa taxifolia, Halophila ovalis and Zostera capricorni and an adult were added to replicate containers $(\mathrm{n}=28)$. The 3 macrophytes and adult $A$. trapezia were randomly placed at equal distances apart around the inside of the container prior to the addition of recruits.

Expt 2-Do recruits show preference for particular macrophytes in the absence of conspecifics? Expt 1 indicated a strong preference of recruits for adults (see 'Results'). Soft-sediment invertebrates will, however, settle on a range of substrata, even in the absence of positive cues (Woodin 1991). Expt 2 investigated whether recruits exhibit habitat choice in favour of a specific macrophyte in the absence of adults. Approximately $2 \mathrm{~g}$ (wet weight) each of Caulerpa taxifolia, Halophila ovalis and Zostera capricorni was added to replicate $9 \mathrm{~cm}$ diam. petri dishes $(\mathrm{n}=40)$. Treatments were randomly placed at equal distances around the inside of the petri dishes prior to the addition of recruits.

Expt 3-Do recruits show a preference for a particular habitat within adult populations? Expt $3 \mathrm{mim}-$ icked the main habitat choices of recruits in invaded and uninvaded adult beds. In particular, we wanted to test whether the different sediment found in invaded and uninvaded beds (authors' unpubl. data) influenced the habitat choice of recruits. Recruits were offered a choice of sediment from the bare habitat, sediment from the bare habitat with an adult Anadara trapezia, sediment from the Caulerpa taxifolia habitat, sediment from the $C$. taxifolia habitat with an adult $A$. trapezia and sediment from the $C$. taxifolia habitat with $C$. taxifolia. A single replicate of each habitat was placed into containers $(\mathrm{n}=46)$ each of which had been divided into 5 sections (3 $\mathrm{cm}$ deep). Substrata were randomly assigned to sections within each container. The sediment for each section was added first, so that all sediment was at the same level. Adult A. trapezia or C. taxifolia ( $1 \mathrm{~g}$ wet $\mathrm{wt}$ ) were then added to the appropriate section.

Expt 4-Do recruits show a preference for live or dead adults? Expt 4 investigated whether recruits were responding to the structure (topography) of the adult shell or potential chemical cues from the adults. A single live adult and a single empty adult shell were placed in containers ( $\mathrm{n}=43$ ), and recruits were allowed to choose between them. To create a surface similar to that of a live adult, but inert and sterile, 2 shell halves of dead adult Anadara trapezia were cleaned and glued together at the hinge with a small amount of cyanoacrylate-based glue and autoclaved at $120^{\circ} \mathrm{C}$ for $1 \mathrm{~h}$.

Predation on recruits. We investigated the effects of fish predation on Anadara trapezia recruits in Caulerpa taxifolia and bare sediment habitats. In dense $C$. taxifolia beds, bare sediment habitat was created by removing $C$. taxifolia from a $30 \times 30 \mathrm{~cm}$ area. Two adults, each with 1 recruit attached, were collected from sparse $C$. taxifolia. One of each pair was placed in the middle of the bare sediment plot, and the other was placed next to it $(<40 \mathrm{~cm}$ away) under the C. taxifolia canopy. Adult A. trapezia were gently pushed into the sediment so that ca. 20 to $30 \%$ of the shell remained above the sediment, with the recruits attached to the shells above the sediment, to mimic how both adults and recruits typically sit in the sediment naturally (authors' pers. obs.). Mesh cages (10 cm diam., $20 \mathrm{~cm}$ high, $10 \times 10 \mathrm{~mm}$ mesh size) were temporarily placed over adults after they had been placed in their perspectives habitat, until 15 replicate pairs had been set up. Once all the adults with recruits were in place, the cages were removed and the plots were monitored at a distance of 5 to $6 \mathrm{~m}$ for $15 \mathrm{~min}$, after which time the adults were inspected for the presence or absence of recruits, and results were recorded.

\section{RESULTS}

\section{Effects of habitat and site on the density of recruits}

The density of Anadara trapezia recruits ranged from 0 to $680 \mathrm{~m}^{-2}$. Of the 259 recruits sampled in the cores (pooled across habitats and sites), $4.6 \%$ were found in sediment, $3.9 \%$ were attached to adults, $2.7 \%$ were attached to Zostera capricorni, 30.1\% were attached to dense Caulerpa taxifolia and $58.7 \%$ were attached to sparse $C$. taxifolia. There were significant differences in densities of recruits among habitats, but not among sites, and the interaction was not significant (Fig. 1, Table 1). For the habitat comparison, Tukey's test indicated a significantly higher density of recruits in sparse C. taxifolia than in both bare sediment and $Z$. capricorni habitats $(p<0.05)$. Differences in densities between dense $C$. taxifolia versus bare sediment, dense $C$. taxifolia versus $Z$. capricorni and bare sediment versus $Z$. capricorni were all non-significant $(\mathrm{p}>$ 0.05). The densities of recruits $\left(\mathrm{m}^{-2}\right)$ in C. taxifolia in Iron Bark Bay and Pigeon House View, areas that did 


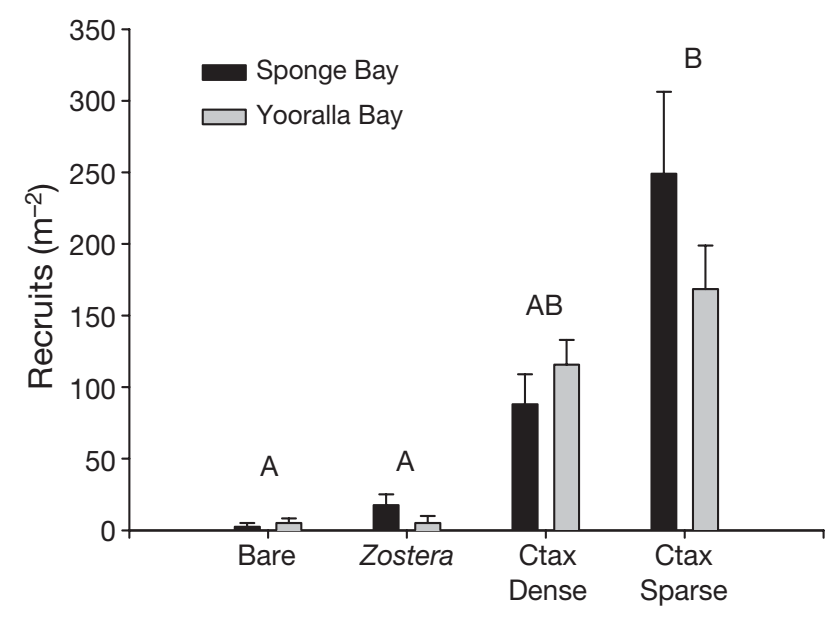

Habitat

Fig. 1. Anadara trapezia. Mean $( \pm \mathrm{SE}, \mathrm{n}=10)$ number of recruits $\left(\mathrm{m}^{-2}\right)$ in bare sediment (bare), Zostera capricorni (Zostera), dense Caulerpa taxifolia (Ctax dense) and sparse C. taxifolia (Ctax sparse) habitats. Habitats with significant differences are indicated by different letters above bars

(Tukey's test, $\alpha=0.05$ )

not contain adult $A$. trapezia, were $110.7( \pm 29.9)$ and $279( \pm 57.0)$, respectively.

Recruit densities in both Sponge Bay and Yooralla Bay increased with increasing Caulerpa taxifolia biomass once $C$. taxifolia biomass reached a threshold of approximately $100 \mathrm{~g}$ dry wt $\mathrm{m}^{-2}$ but decreased again when C. taxifolia biomass exceeded 250 to $300 \mathrm{~g}$ dry wt $\mathrm{m}^{-2}$ (Fig. 2).

The number of recruits on adult Anadara trapezia ranged from 0 to 11 . The mean $( \pm \mathrm{SE})$ number of recruits per adult was much higher in Caulerpa taxifolia $(0.95 \pm 0.25$ and $1.23 \pm 0.31$ for Sponge Bay and Yooralla Bay, respectively) than in the bare sediment habitat at both sites $(0.06 \pm 0.03$ and 0 for Sponge Bay and Yooralla Bay, respectively; Fig. 3A). Approximately $40 \%$ of the adults in the C. taxifolia habitat at both sites had recruits attached, whereas very few adults sampled from bare sediment had recruits attached (Fig. 3B).

Table 1. 2-factor ANOVA examining the effects of site and habitat on recruit density (data square root transformed)

\begin{tabular}{|lrrrr|}
\hline $\begin{array}{l}\text { Source of } \\
\text { variation }\end{array}$ & df & \multicolumn{1}{c}{ MS } & $F$ & $p$ \\
\hline Site & 1 & 7.812 & 0.783 & 0.379 \\
Habitat & 3 & 290.613 & 17.183 & 0.022 \\
Site $\times$ habitat & 3 & 16.913 & 1.696 & 0.176 \\
Error & 72 & 9.974 & & \\
\hline
\end{tabular}

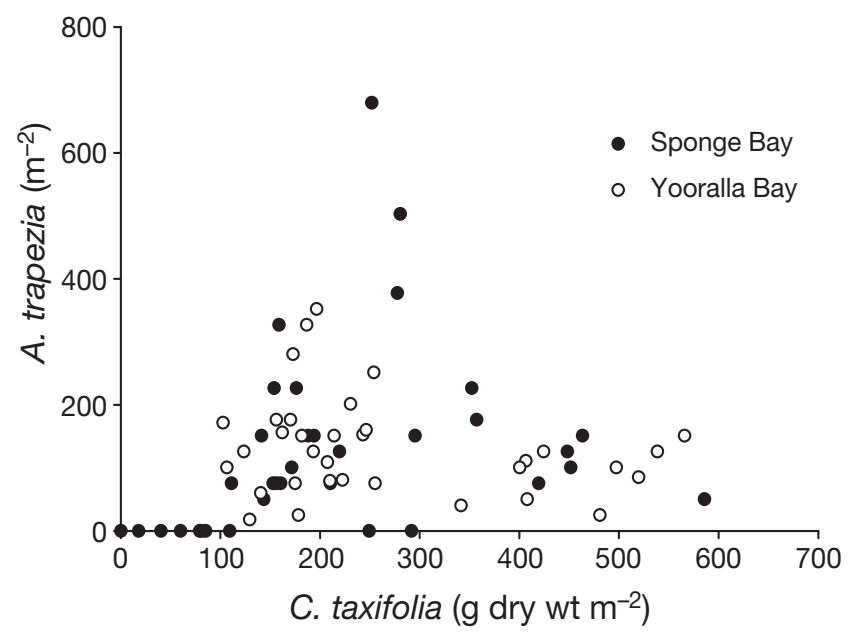

Fig. 2. Anadara trapezia. Number of recruits $\left(\mathrm{m}^{-2}\right)$ versus biomass of Caulerpa taxifolia ( $\mathrm{g}$ dry $\mathrm{wt}^{-2}$ ) at Sponge Bay and Yooralla Bay
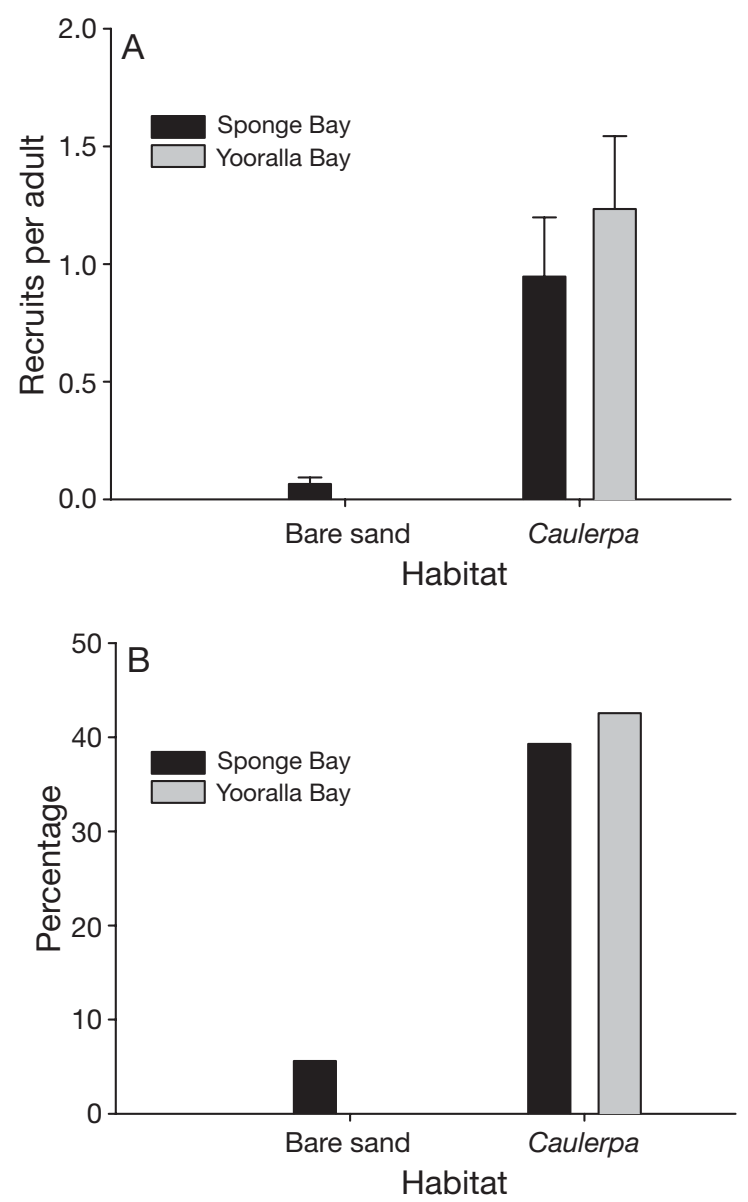

Fig. 3. Anadara trapezia. (A) Mean number $( \pm$ SE) of recruits attached to adult $A$. trapezia in Caulerpa taxifolia and bare sediment habitats, and (B) the percentage of adults with recruits attached in both habitats 


\section{Habitat choice of recruits}

In Expt 1, the choice of recruits was non-random $\left(\chi_{0.05}^{-2}=807.65, \mathrm{df}=4, \mathrm{p}<0001\right)$, with $82 \%$ of recruits found attached to adults (Fig. 4A). In Expt 2, recruits exhibited no choice among the 3 macrophytes $\left(\chi^{-2}{ }_{0.05}=\right.$ $3.4, \mathrm{df}=3, \mathrm{p}=0.192)$, although higher numbers of recruits were recovered on Zostera capricorni $(37.5 \%$; Fig. 4B). In Expt 3, the choice of recruits was again non-random $\left(\chi_{0.05}^{-2}=31.56, \mathrm{df}=4, \mathrm{p}<001\right)$, with the majority of the recruits recovered from adults in the 2 treatments containing adult Anadara trapezia (39\% on Caulerpa taxifolia sediment + adult and $41 \%$ on bare sediment + adult; Fig. 4C). Recruits almost completely avoided the 2 sediment only treatments. In Expt 4, more recruits were recovered from live $(70 \%)$ than from dead adults $(30 \%)\left(\chi^{-2}{ }_{0.05}=7.259, \mathrm{df}=1, \mathrm{p}<0.01\right.$; Fig. 4D), suggesting that recruits were potentially responding to chemical cues from adults.

\section{Predation on recruits}

Yellowfin bream Acanthopagrus australis were observed foraging on all adult Anadara trapezia in the bare habitat during our experiment. A. australis were never observed foraging on adult $A$. trapezia in Caulerpa taxifolia. None of the recruits on adults in the bare habitat were recovered after $15 \mathrm{~min}$, whereas all recruits remained attached to adults within the $C$. taxifolia habitat.
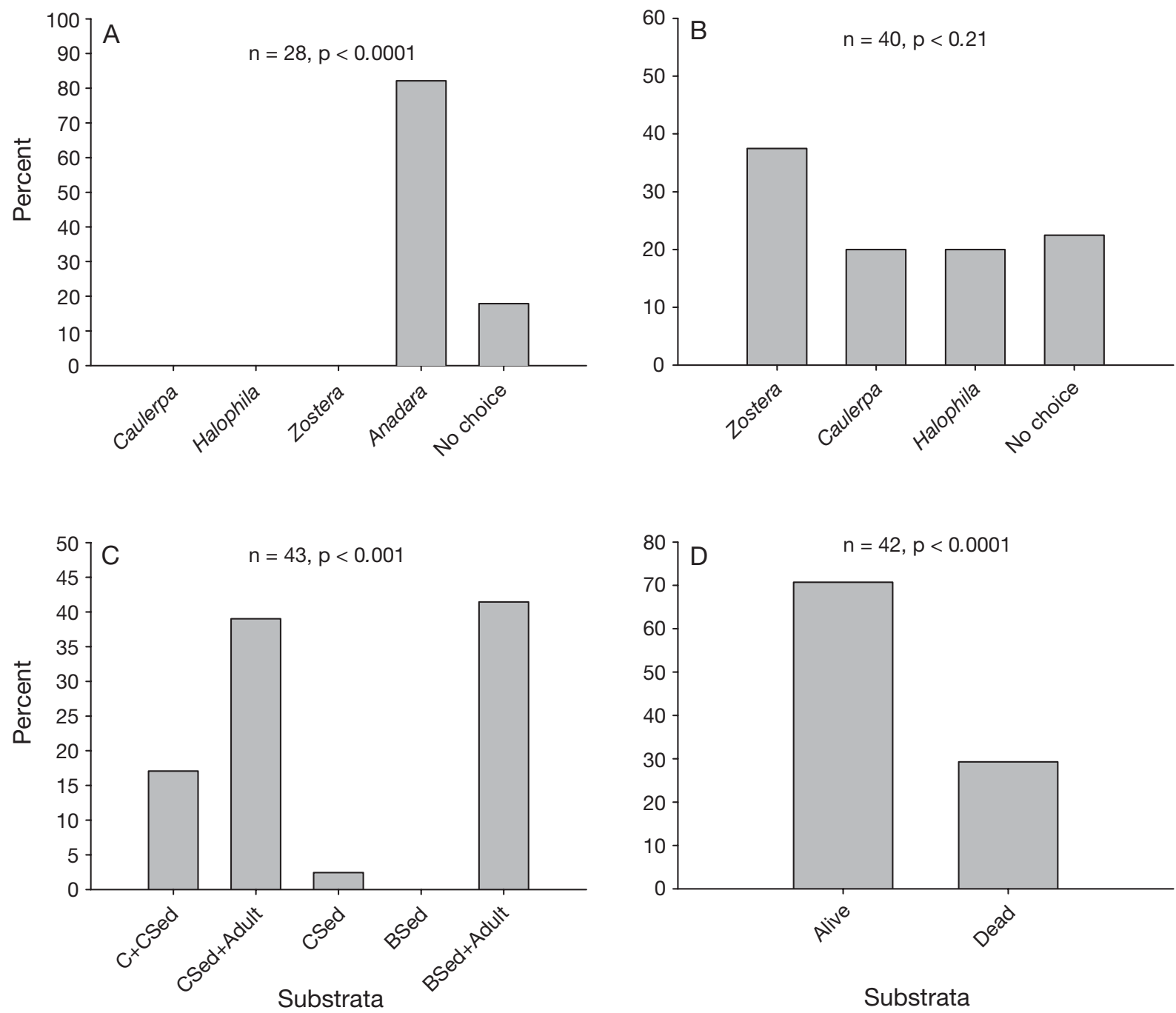

Fig. 4. Anadara trapezia. Recruits' choice of habitat (\%) from among (A) Expt 1: Caulerpa taxifolia (Caulerpa), Halophila ovalis (Halophila), Zostera capricorni (Zostera), a single adult A. trapezia (Anadara) and no choice; (B) Expt 2: Z. capricorni, C. taxifolia, H. ovalis and no choice; $(C)$ Expt 3:C. taxifolia $+C$. taxifolia sediment $(C+C S e d)$, adult A. trapezia + C. taxifolia sediment $(C S e d$ + Adult), C. taxifolia sediment only (CSed), bare sediment only (BSed) and bare sediment + adult A. trapezia (BSed + Adult); and (D) Expt 4: 1 live and 1 dead adult $A$. trapezia 


\section{DISCUSSION}

The effects of Caulerpa taxifolia on invaded environments are generally considered to be detrimental. Contrary to this prediction, we found higher densities of Anadara trapezia recruits in C. taxifolia than in bare sediment and seagrass habitats. Although this finding goes against the perception of $C$. taxifolia, it is consistent with findings which demonstrate the positive effects of other invasive species on the abundance and diversity of invertebrates in soft-sediment habitats (e.g. Posey 1988, Crooks 1998, Bially \& MacIsaac 2000). However, these studies were conducted at the community level, and, to our knowledge, ours is the first to demonstrate a role for invasive species in facilitating recruitment into soft-sediment systems.

The idea that seagrasses provide a refuge from predation for soft-sediment fauna by increasing habitat complexity is well documented (see Orth et al. 1984, Williams \& Heck 2001 for reviews). Provision of a refuge has been suggested as a mechanism by which dense aggregates of invasive species increase faunal diversity and abundance compared to nearby unvegetated substrata (Crooks 1998, Bially \& MacIsaac 2000), although this had not previously been formally tested. Our simple predation experiment indicated that the increased habitat complexity of Caulerpa taxifolia compared to bare sediments reduced predation on recruits by fish and may, in part, explain the differences in densities of recruits between the 2 habitats.

The reasons for the lower densities of Anadara trapezia recruits in Zostera capricorni than in Caulerpa taxifolia are unclear. Different levels of predation by fish may explain differences between $Z$. capricorni and C. taxifolia, but we did not measure fish predation in $Z$. capricorni. Alternative hypotheses include predation by epifauna, lower survivorship due to increased stress resulting from desiccation within $Z$. capricorni beds (seagrasses in both bays only occur from the low intertidal to very shallow subtidal areas fringing the bays) and differences in larval supply to different habitats. Although pre-settlement processes (e.g. larval supply) can influence the abundance of post-settlement softsediment bivalves (e.g. Peterson et al. 1996), there is little evidence that soft-sediment environments are recruitment limited (Olafsson et al. 1994). Furthermore, many studies have shown that Zostera spp. have highly positive effects on the abundance of soft-sediment bivalves when compared to unvegetated substrata (e.g. Peterson 1986, Skilleter 1994).

Studies on native seagrasses also indicate that the relationship between faunal abundance and macrophyte biomass is generally non-linear, with a threshold value of macrophyte biomass reached before predation is reduced (Heck \& Orth 1980, Orth et al. 1984).
Heck \& Orth (1980) proposed that vegetation can become so dense that conditions become unfavourable for macroinvertebrates (potentially due to increasingly high organic content of sediments) and, consequently, species diversity and abundance decline. Increasing organic content of sediments can lead to anoxic or hypoxic conditions and a buildup of toxic by-products (e.g. ammonia and sulphide) associated with the decomposition of the organic material (Diaz \& Rosenberg 1995, Hyland et al. 2005). A decrease in species diversity and abundance associated with high organic loads in surface sediments has been clearly demonstrated in a marine pollution context (reviewed in Diaz \& Rosenberg 1995). Again, our results for Caulerpa taxifolia appear analogous to those described for native macrophytes and support the hypothesis of highest invertebrate abundance at intermediate macrophyte densities. No recruits were found on C. taxifolia until a biomass of ca. $100 \mathrm{~g}$ dry wt $\mathrm{m}^{-2}$ was reached. Densities then increased as C. taxifolia biomass increased until a threshold $C$. taxifolia biomass of ca. 250 to $300 \mathrm{~g}$ dry $\mathrm{wt} \mathrm{m}^{-2}$ was reached. However, further increases in biomass resulted in a decrease in the density of recruits. Sediments containing dead macrophyte material turn black once penetrated by C. taxifolia rhizoids, due to the presence of sulphide (Chisholm \& Moulin 2003). Although Anadara trapezia recruits appeared to be epibenthic, they were most often found attached to the stolons of $C$. taxifolia (authors' pers. obs.). Therefore, increasingly anoxic or hypoxic conditions and high levels of sulphide may lead to a reduction of recruit abundance at high C. taxifolia biomass. Reduced dry weight of soft tissue and lower densities of adult $A$. trapezia in areas of dense C. taxifolia compared to those found in bare sediment habitats further support the hypothesis of increased physiological stress at high vegetation biomass (authors' unpubl. data).

Results from the habitat choice experiments suggested that other processes (e.g. adult-juvenile interactions) may also be important in determining the observed patterns of recruit densities among habitats. Recruits demonstrated a strong affinity for adults, and this gregarious behaviour was potentially due to positive chemical cues from live adults. However, we do not know whether such cues are waterborne (e.g. excretory products) or surface-associated biofilms (e.g. diatoms or bacteria), or whether juveniles respond only to adult Anadara trapezia or also to other bivalves. Although the glue used to join the valves together to create the dead adults could have acted as a negative cue encouraging juveniles to move away from these shells, this appears unlikely, as juveniles were found attached to the hinge region where the glue was applied. In the field, we found a small number of other 
juvenile clams (e.g. venerids and tellinids) also attached to adult $A$. trapezia, suggesting that other bivalves were also responding to the presence of adult A. trapezia (authors' unpubl. data). Since A. trapezia is the only large epifaunal bivalve in Yooralla Bay and Sponge Bay, we could not test whether recruits respond similarly to the presence of other soft-sediment bivalves.

Larval settlement and recruitment in bivalves have been shown to be higher in dense seagrass habitats than in lower density areas, often due to changes in hydrodynamic regimes associated with dense seagrass beds (see Orth et al. 1984, Williams \& Heck 2001 for reviews). However, if the density of recruits reflects larval settlement patterns, dense Caulerpa taxifolia habitat does not appear to interfere with settlement, as higher numbers of recruits were found at intermediate C. taxifolia densities (Fig. 2). Although levels of recruitment in soft-sediment bivalves are rarely correlated with larval abundance (Olaffson et al. 1994), adult distributions may be determined by the initial habitat choice of settling larvae. The link between larval habitat selection and the distribution of recruits and adults in the field has been demonstrated in several studies (e.g. Muus 1973, Snelgrove et al. 1998, 2001). However, given that the densities of adult Anadara trapezia in vegetated habitats sampled in this study follow similar patterns to those observed for recruits (i.e. higher in C. taxifolia compared to Zostera capricorni; authors' unpubl. data), densities of recruits may simply reflect adult density. The absence of recruits in the bare sediment habitat, where adult densities are highest, conflicts with this idea, but may be explained by the relatively high levels of predation in that habitat. Recruitment of the ribbed mussel Geukensia demissa and the infaunal bivalve Katelysia scalarina was higher in areas containing adult conspecifics than in other habitats (Peterson \& Black 1993, Nielson \& Franz 1995).

Woodin (1991) argued that recruitment is more likely to be driven by larvae rejecting substrata due to negative cues than by larvae accepting positive cues. Consequently, larvae may settle into environments in the absence of negative cues even though they may exhibit preference for a particular habitat. The high densities of recruits observed in Caulerpa taxifolia at sites where adults were absent, suggest recruits choose a structure over bare sediment (e.g. Expt 3 indicates that, after adults, recruits prefer C. taxifolia to sediment), and provide a further explanation (from predation) for why recruits are found in C. taxifolia.

Caulerpa taxifolia has not previously been demonstrated to enhance recruitment of soft-sediment bivalves. Although predation appears to be a major structuring force, recruit habitat choice (possibly linked to larval settlement choice) may also be important in determining the observed density patterns. In light of the potential impacts (both positive and negative) that $C$. taxifolia has on invaded soft-sediment ecosystems, a major challenge for researchers will be in determining its consequences for the population dynamics of soft-sediment fauna. In particular, how well recruits grow and survive in C. taxifolia, or whether they move to another habitat post-settlement, will have important implications in determining the extent to which enhanced recruitment contributes to future population growth.

Acknowledgements. We thank Louise McKenzie for assisting with sample collection and sorting, and Drs. Rocky de Nys and Bob Creese for providing valuable comments on the manuscript.

\section{LITERATURE CITED}

Bellan-Santini D, Arnaud PM, Bellan G, Verlaque M (1996) The influence of the introduced alga, Caulerpa taxifolia, on the biodiversity of the Mediterranean marine biota. J Mar Biol Assoc UK 76:235-237

Beukema JJ, Dekker R (2003) Redistribution of spat-sized Macoma balthica in the Wadden Sea in cold and mild winters. Mar Ecol Prog Ser 265:117-122

Bially A, MacIsaac HJ (2000) Fouling mussels (Dreissena spp.) colonize soft sediments in Lake Erie and facilitate benthic invertebrates. Freshw Biol 43:85-97

Ceccherelli G, Cinelli F (1997) Short term effects of nutrient enrichment of the sediment and interactions between the seagrasses Cymodocea nodosa and the introduced green alga Caulerpa taxifolia in a Mediterranean bay. J Exp Mar Biol Ecol 217:165-177

Ceccherelli G, Sechi N (2002) Nutrient availability in the sediment and the reciprocal effects between the native seagrass Cymodocea nodosa and the introduced green alga Caulerpa taxifolia in a Mediterranean bay. Hydrobiologia 474:57-66

Chisholm JRM, Moulin P (2003) Stimulation of nitrogen fixation in refractory organic sediments by Caulerpa taxifolia (Chlorophyta). Limnol Oceanogr 48:787-794

Chisholm JRM, Dauga C, Ageron E, Grimont PAD, Jaubert JM (1996) 'Roots' on mixotrophic algae. Nature 381:382

Creese RG, Davies AR, Glasby TM (2004) Eradicating and preventing the spread of the invasive alga Caulerpa taxifolia in NSW. NSW Fish Final Rep Ser 64:1-110

Crooks JA (1998) Habitat alteration and community-level effects of an exotic mussel, Musculista senhousia. Mar Ecol Prog Ser 162:137-152

Crooks JA (2002) Characterizing ecosystem-level consequences of biological invasions: the role of ecosystem engineers. Oikos 97:153-166

Cummings VJ, Thrush SF (2004) Behavioural response of juvenile bivalves to terrestrial sediment deposits: implications for post-disturbance recolonisation. Mar Ecol Prog Ser 278:179-191

Diaz RJ, Rosenberg R (1995) Marine benthic hypoxia: a review of its ecological effects and the behavioural responses of benthic macrofauna. Oceanogr Mar Biol Annu Rev 33:245-303 
Edgar GJ (2000) Australian marine life: the plants and animals of temperate waters. Reed New Holland, Sydney

Glasby TM, Gibson PT, Kay S (2005) Tolerance of the invasive marine alga Caulerpa taxifolia to burial by sediment. Aquat Bot 82:71-81

Gribben PE, Helson J, Millar R (2004) Population abundance estimates of the New Zealand geoduck clam, Panopea zelandica, using North American methodology: Is the technology transferable? J Shellfish Res 23(3):683-691

Grosholz ED, Ruiz GM, Dean CA, Shirley KA, Maron JL, Conners PG (2000) The impacts of a nonindigenous marine predator in a California bay. Ecology 81:1206-1224

Heck KL Jr, Orth RJ (1980) Seagrass habitats: the roles of habitat complexity, competition and predation in structuring associated motile macroinvertebrate assemblages. In: Kennedy VS (ed) Estuarine perspectives. Academic Press, New York, p 449-464

Hewitt JE, Legendre P, McArdle BH, Thrush SF, Bellehumeur C, Lawrie SM (1997) Identifying relationships between adult and juvenile bivalves at different spatial scales. J Exp Mar Biol Ecol 216:77-98

Hyland J, Balthis L, Karakassis I, Magni P, Petrov A, Shine J, Vestergaard O, Warwick R (2005) Organic carbon content of sediments as an indicator of stress in the marine benthos. Mar Ecol Prog Ser 295:91-103

Irlandi EA (1994) Large- and small-scale effects of habitat structure on rates of predation: how percent coverage of seagrass affects rates of predation and siphon nipping on an infaunal bivalve. Oecologia 98:176-183

Irlandi EA, Peterson CH (1991) Modification of animal habitat by large plants: mechanisms by which seagrasses influence clam growth. Oecologia 87:307-318

Jaubert JM, Chisholm JRM, Ducrot D, Ripley HT, Roy L, Passeron-Seitre G (1999) No deleterious alterations in Posidonia beds in the Bay of Menton (France) eight years after Caulerpa taxifolia colonization. J Phycol 35:1113-1119

Jousson O, Pawlowski J, Zaninetti L, Zechman FW and 5 others (2000) Invasive alga reaches California. Nature 408: $157-158$

Levi F, Francour P (2004) Behavioural response of Mullus surmuletus to habitat modification by the invasive macroalga Caulerpa taxifolia. J Fish Biol 64:55-64

Mack RN, Simberloff D, Lonsdale WM, Evans H, Clout M, Bazzaz FA (2000) Biotic invasions: causes, epidemiology, global consequences, and control. Ecol Appl 10:689-710

Meinesz A, Belsher T, Thibaut T, Antolic B and 18 others (2001) The introduced green alga Caulerpa taxifolia continues to spread in the Mediterranean. Biol Invasions 3:201-210

Muus K (1973) Settling, growth and mortality of young bivalves in the Oresund. Ophelia 12:79-116

Neira C, Levin LA, Grosholz ED (2005) Benthic macrofaunal communities of three sites in San Francisco Bay invaded by hybrid Spartina, with comparison to uninvaded habitats. Mar Ecol Prog Ser 292:111-126

Nielson KJ, Franz DR (1995) The influence of adult conspecifics and shore level recruitment of the ribbed mussel Geukensia demissa (Dilwyn). J Exp Mar Biol Ecol 188: 89-98

Olafsson EB, Peterson CH, Ambrose WG Jr (1994) Does recruitment limitation structure populations and communities of macro-invertebrates in marine and soft sediments: the relative importance of pre- and post-settlement processes. Oceanogr Mar Biol Annu Rev 19:33-38
Orth RJ, Heck KL Jr, van Montfrans J (1984) Faunal communities in seagrass beds: a review of the influence of plant structure and prey characteristics on predator-prey relationships. Estuaries 7:339-350

Pecon-Slattery J, Vrijenhoek RC, Lutz RA (1991) Heterozygosity, growth, and survival of the hard clam, Mercenaria mercenaria, in seagrass vs sandflat habitats. Mar Biol 111: $335-342$

Peterson CH (1986) Enhancement of Mercenaria mercenaria densities in seagrass beds: Is pattern fixed during settlement season or altered by subsequent differential survival? Limnol Oceanogr 31(1):200-205

Peterson CH, Black R (1993) Experimental tests of the advantages and disadvantages of high density for two coexisting cockles in a Southern Ocean lagoon. J Anim Ecol 62: 614-633

Peterson CH, Kennicutt MC, Green RH, Harper DE Jr, Powell EN, Roscigno PF (1996) Ecological consequences of environmental perturbations associated with offshore hydrocarbon production: a perspective on long-term exposure in the Gulf of Mexico. Can J Fish Aquat Sci 53:2637-2654

Posey MH (1988) Community changes associated with the spread of an introduced seagrass, Zostera japonica. Ecology 69:974-983

Richardson CA, Walker P (1991) The age structure of a population of the hard-shell clam, Mercenaria mercenaria from Southampton water, England, derived from acetate peel replicas of shell sections. ICES J Mar Sci 48:229-236

Ross DJ, Johnson CR, Hewitt CL (2003) Variability in the impact of an introduced predator (Asterias amurensis: Asteroidea) on soft-sediment assemblages. J Exp Mar Biol Ecol 257-278

Skilleter GA (1994) Refuges from predation and the persistence of estuarine clam populations. Mar Ecol Prog Ser 109:29-42

Snelgrove PVR, Grassle JP, Butman CA (1998) Sediment choice of settling larvae of the bivalve, Spisula solidissima (Dillwyn), in flow and still water. J Exp Mar Biol Ecol 231: 171-190

Snelgrove PVR, Grassle JF, Petrecca RF, Stocks KI (2001) The role of colonization in establishing patterns of community composition and diversity in shallow-water sedimentary communitites. J Mar Res 59:813-831

Talman SG, Keough MJ (2001) Impact of an exotic clam, Corbula gibba, on the commercial scallop Pecten fumatus in Port Phillip Bay, south-east Australia: evidence of resource-restricted growth in a subtidal environment. Mar Ecol Prog Ser 221:135-143

Villèle de X, Verlaque M (1995) Changes and degradation in a Posidonia oceania bed invaded by the introduced tropical alga Caulerpa taxifolia in the north-western Mediterranean. Bot Mar 38:79-87

Williams SL, Heck KL Jr (2001) Seagrass community ecology. In: Bertness MD, Gaines SD, Hay ME (eds) Marine community ecology. Sinuaer Associates, Sunderland, MA, p 317-337

Wonham MJ, O'Connor M, Harley CDG (2005) Positive effects of a dominant invader on introduced and native mudflat species. Mar Ecol Prog Ser 289:109-116

Woodin SA (1991) Recruitment of infauna: Positive or negative cues? Am Zool 31:797-807

Wright JT (2005) Differences between native and invasive Caulerpa taxifolia: a link between asexual fragmentation and abundance in invasive populations. Mar Biol 147: $559-569$

Submitted: September 15, 2005; Accepted: December 7, 2005

Proofs received from author(s): June 30, 2006 